\title{
Students' Attitudes and Perceptions of Smart Online Learning through Podcast Content Development
}

\author{
https://doi.org/10.3991/ijim.v15i21.24909 \\ Asep Herry Hernawan $\left.{ }^{(}\right)$, Laksmi Dewi, Ahmad Fajar Fadlillah, Budi Setiawan \\ Universitas Pendidikan Indonesia, Bandung, Indonesia \\ asepherry@upi.edu
}

\begin{abstract}
The COVID-19 pandemic spreading around the globe has affected many fields of human life, including educational services. They have been closed for months to eradicate the transmission of the virus. Educational institutions, as well as podcasts, have developed several online learning media. This study investigated the students' attitudes and perceptions towards creating content for online learning materials/content by utilising podcasts in innovative learning. An online survey was conducted involving 84 students as the research sample by Educational Technology study programme, Faculty of Educational Sciences, Universitas Pendidikan Indonesia. It applied data summarisation for the perception aspect through a 5-point continuum scale on frequency and percentage on data analysis. Furthermore, the attitudes and perceptions consensus were calculated by using the formula from Tastle and Wierman for each statement. The study's results showed that most respondents $(80 \%)$ stated that they were about to be enthusiastic, welcoming a new pattern of the instructional process by applying podcasts to develop subject content. The findings show that the respondents' attitudes and perceptions towards podcast content development for smart learning are very positive with efficiency $(80 \%)$, accessibility $(90 \%)$, interactivity $(90 \%)$ and quality $(82 \%)$. They preferred to access online learning materials by maximising the use of smartphones as its effective and efficient reason for brief and meaningful content by considering the size and broadband.
\end{abstract}

Keywords—-smart learning, attitude, perceptions, online learning, podcast

\section{Introduction}

The fast and sophisticated development of online learning by distance education has resulted in reconstructing and redesigning the learning material for students to fit the students' needs. School-related educational services have made some efforts by using multimedia and software programs to prepare and develop content for online courses. Every multimedia or related application provides some features to encourage its content to be designed using particular media referring to its medium and method [1]. The continuation of new technologies inventions also leads to excitement and attention among educators and related practitioners to find effective ways to include them in educational guidelines. The fact is that a significant population of students, who are 
familiar with wireless technologies in any form available like mobile phones, mp3 players, iPod and, PDA (Personal Digital Assistant) devices, and educators' explorations for learning access bring the educational process to be accessible and portable [1]. The podcast is relatively one of the new paradigms in online learning as part of webcasting in real-time broadcasting audio or video capture over the Internet, generally in mp3 format. It makes it possible for users to download its content in both forms on digital media devices such as computers and smartphones. Instead of entertainment for personal or individual purposes, the podcast has prospective added value in educational sector intentions. It has been used in many universities around the world by applying this technology through capital investment to give their students the best resources or access supporting their studies, including education [1]; general science, and astronomy [2, 3]; geography [4]; medical [5]; and computer science [6, 7].

On the other hand, the existence of alternative learning media in audio form is very limitedly used as the learning resources in higher education. What is seen as a medium for learners to gain learning objectives is seen by most of the lecturers in the faculty as something that bring objective into realia, visible objects, visual capture or speech. The traditional approach seems to be dominant in most of the learning approaches. Technology for education is the key for change by means of ICT (Information Communication and Technology) [65]. The innovation and/or media diversity is very low in other forms. It is rarely found that they develop or create learning media by focusing on sound or voice as the main asset to transfer knowledge of a particular course. The needs of media diversity come to its maximum point faced with the pandemic situation of COVID-19 where it occurred as a flash turning point of instructional process from direct meeting to an indirect way through online meeting. It is predicted by many experts in the medical field that the COVID-19 pandemic will last for few years more, creating significant changes in human aspects of life in a short period, not only in daily life but also in psychological and mental aspects such as attitudes and behaviors, including in education. As a result, typical traditional lecturers/educators had problem with giving learning experiences and goals in a varied and creative way. To have successful adoption of digital literacy or e-learning implementation, it is very vital to know and consider students' perceptions and attitudes [66]. It is very essential to bridge the gap that has occurred. Considering learners' types with regard to the auditory of Millennial generations from demographic perspective and characteristics of media which should be capable, practical, effective and efficient to be used and accessed anywhere and anytime [1] and also the significance of its usability and design [67], podcasting is one of the most recommended and preferred by teachers to meet the dynamic situations and conditions mentioned above.

There are two forms of podcasting widely recognized and used by almost all educators: repetitive, i.e., demonstrations and lecturing slides, recording in lectures; [8], and complementary, i.e., external content resources for interview [43]. Podcasting provides opportunities for educators to have a wide range of objectives as a substantial viable device for the two forms, such as open and distance learning [1, 9]. It also facilitates learning characteristics such as slow learners, students with reading disabilities, auditory learning style and enrichment for highly motivated students. As one of the media in educational technology, podcast contributes to uplifting academic achievement, enabling them to learn both independently and by expository lecturing as individuals. By providing the possibility to encourage measurable performance in education, 
technologies for education and the podcast have become one of the valuable resources to reach the goals set in learning outcomes $[10,11]$. There are several definitions defined by experts in varied contexts related to podcasts. It has the ability to stimulate acoustics and videotape pictures in motion as resources for learning [12]. It brings about real experiences connected with radio, Internet and materials for a film [13]. It has become a method to transfer any digital-based file over the Internet to iPods and computers as portable media [14]. The podcast allows students to learn how to motivate themselves actively towards the content [15]. The usage of podcasts assists them in giving space for independent and convenient learning [16]. It is seen as the primary tool to help them cope with new competence and increase academic achievement by fulfilling tasks, which are the characteristics of being independent $[17,18]$. Podcasts contribute to helping educational institutions and students in the teaching-learning perspective [19].

From the higher education, university-level perspective, several studies have exposed evidence that it has becomes an effective tool for learning. The students from the central business and dentistry program have stated that podcasts have supported them in completing notes compared to the written sources [20, 21]. Time management or adjustment principles as needs are increasing for class discussion and learning activities based on higher-order thinking skills [22]. Isolating anxiety by offering a wide range of areas in distance education promotes the feeling of being together for learners [23]. Besides, it enables motivates students by obtaining a sense of teacher-student contact in various ways for them to learn [24].

The students' attitudes and perceptions towards the usage of the podcast for online learning resources are based on three terms of readiness aspects as follows: (1) students' preference in material delivery during the instructional process; (2) the trust in electronic and Internet-based media to support their learning performance in confidence; and (3) the competence to have independent or self-regulated learning [25]. A 13-item instrument was used to find out or quantify students' attitudes and behavior [26, 27]. Another researcher stated that surveys or online questionnaires are used to measure the aspects of readiness relying on two components, namely 'self-learning management and e-learning comfort' [28]. Utilizing media development and its content for online learning comes as a factor in identifying students' readiness through self-directed learning [29, 30, 31, 32], learner supervision [33], self-efficacy by internet and computer $[34,35,36]$, learning motivation $[37,38]$, and online communication [39, 40]. The innovations or actions to empower effective results towards the learning process and goals by the content or material subject development of online learning are necessary to know students' needs. Some studies have presented their perceptions through some indications as appeared on the interactions between teachers and students in instructional activities by paying attention to the self-concept in the academic field [41] [42], technology and users' usage skill [47], opportunity to change through engagement [43, 44], clear instructions and feedback [45], well- managed instructors and recent technologies [46]. It also correlates to students' expectation and needs towards learning experiences in directing their perception and attitudes [68].

Regarding the significance for a suitable instructional process in media pre-production to meet students' needs, this study pointed out podcasting in higher education, especially among university students, to discover their attitudes and perceptions of using podcasts as a platform or media to develop subject learning materials in an online 
learning environment. In addition, it also investigated the characteristics of the podcast materials used to elaborate its content.

\section{Methodology}

\subsection{Participants}

In this study, participants in the seventh semester of the educational technology study programme, Universitas Pendidikan Indonesia, were chosen as the research sample. A total of 84 students took up the study programme-based elective professional courses as their expertise subject matters in the last semester of in-class lecturing with a total of 12 credits.

\subsection{Procedure}

An online survey through Google Form was designed to gather the data from the participants as the primary source, including an interview. The link was sent to the class captain, who was the critical informant, through a social media group on WhatsApp. Setting up the deadline of submission schedule (time limiter applied on time and date) included 84 students filling out the questionnaire as an online survey by the sharing the link.

\subsection{Data analysis}

The collected data from the online survey included information on demographic characteristics along with students' attitudes and preferences towards online learning development through podcasts. It was evaluated on a 4-point continuum scale (with $4=$ strongly agree and $1=$ least agree/strongly disagree). The calculation in percentage for the aspects measured of attitudes and preferences was formulated following Tavales and Skevoulis' theory [55].

\section{$3 \quad$ Findings}

\subsection{Podcast for education}

As a media which enables downloading from the Internet in the form of audio or video, the podcast is a form of electronic device connected to mobile phones, tablets, laptops, iPod or mp3 players to enjoy [48]. It includes three categories of content available to the public through the Internet: audio, enhanced and video podcasts.

From the educational perspective, it has become the primary attention for educators as an alternative way to conduct instructional processes [49]. However, as sophisticated technology develops, it gains a positive spotlight for educators to transfer knowledge effectively and efficiently. The podcast devices and their electrical tools for learning are described in Figures 1 and 2; 


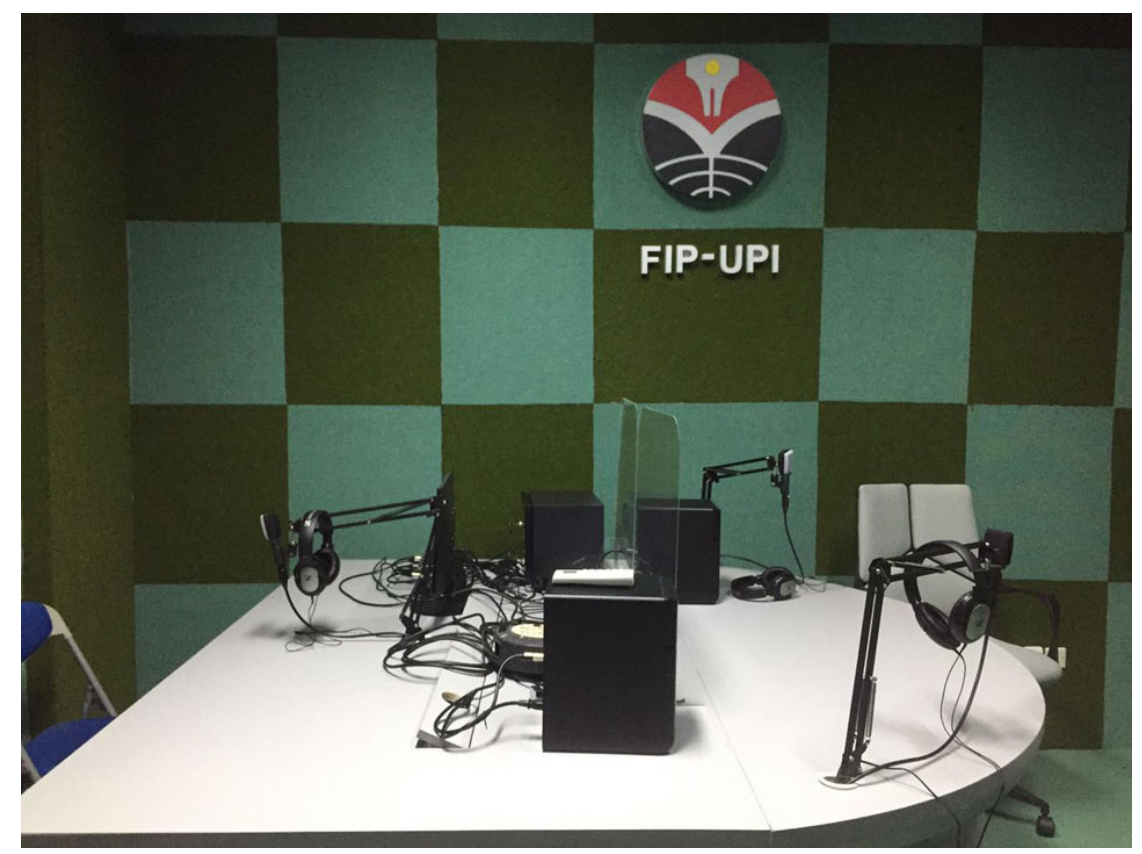

Fig. 1. Podcast electronic devices for education

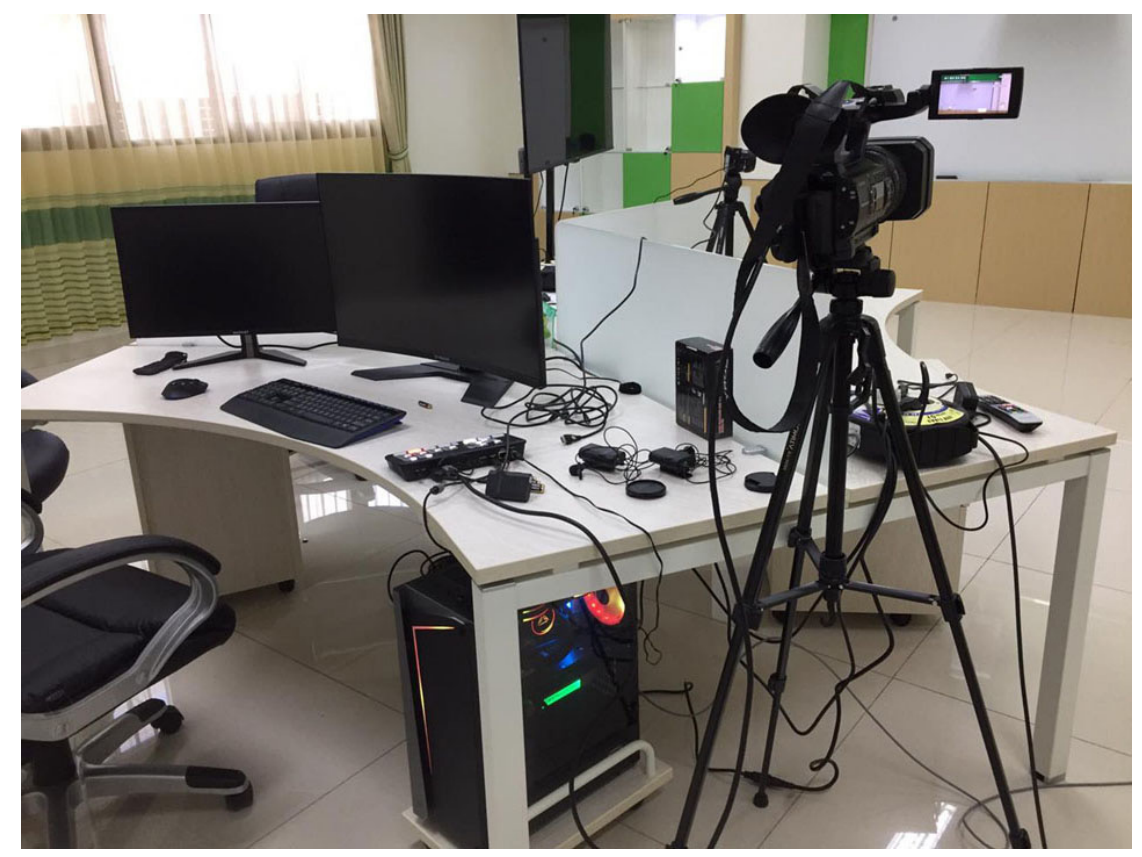

Fig. 2. Integrated podcasts devices 


\subsection{Respondents demographic details information}

The included variables in the demographic features were age, sex and residence. The average age of respondents taking part in this online survey was 19 years. The number of male respondents $(50,59.6 \%)$ was more than female respondents $(34,40.4 \%)$, whereas their place of residence was mainly situated in rural areas $(60,71 \%)$ and the remaining were $(24,29 \%)$ in urban areas. Details of the demographic information can be seen in Table 1 .

Table 1. Respondents' demographic information

\begin{tabular}{|c|c|c|}
\hline & & $N=84$ \\
\hline Demographic Variables & & Percentage \\
\hline \multirow[t]{2}{*}{ Sex } & Male & $50.9 \%$ \\
\hline & Female & $40.4 \%$ \\
\hline \multirow[t]{2}{*}{ Residence } & Rural & $71 \%$ \\
\hline & Urban & $29 \%$ \\
\hline
\end{tabular}

\subsection{Attitudes}

The students' responses showing their attitudes towards the podcasts as a media for smart online learning content development were relatively positive. They believed that it contributed to their studies. As divided by two types of podcasts ( $46 \%$ repetitive and $30 \%$ supplemental at very high contributions), most of the students determined that podcasting contributed significantly to a change in their attitudes towards learning. Table 2 presents the percentages on both types of podcasts applied to the courses based on students' responses.

Table 2. Students' attitude to podcasts

\begin{tabular}{|l|c|c|c|c|c|}
\hline $\begin{array}{c}\text { Type of } \\
\text { Podcast }\end{array}$ & $\begin{array}{c}\text { Very High } \\
\text { Contribution } \\
(\mathbf{\% )}\end{array}$ & $\begin{array}{c}\text { High } \\
\text { Contribution } \\
\mathbf{( \% )}\end{array}$ & $\begin{array}{c}\text { Fair } \\
\text { Contribution } \\
(\mathbf{\%})\end{array}$ & $\begin{array}{c}\text { Less } \\
\text { Contribution } \\
(\%)\end{array}$ & $\begin{array}{c}\text { Poor } \\
\text { Contribution } \\
(\%)\end{array}$ \\
\hline Supplemental & 30 & 40 & 28 & 2 & 0 \\
\hline Repetitive & 46 & 32 & 22 & 0 & 0 \\
\hline
\end{tabular}

The supplemental attitudes seem to have climbed up than repetitive attitudes. This indicates that podcasting has assisted them in reviewing and emphasizing the course content development in online learning. The technology applied did not decrease their motivation towards joining the class as the basis of the theory states that proper instruction in line with its content includes the consideration for attitude in its design [53]. It reflects one of the essential concepts in education seen from the psychological point of view by enticing them to learn and complete tasks in harmony [50, 51, 52]. In an online learning environment, keeping up student's satisfaction sustainability 
is vital in preventing them from lacking attention which can be accommodated by technology-based content elaboration [54][72][73].

\subsection{Students' perception for podcast content development}

Online class structure. Most of data obtained from the respondents show that they preferred to have recorded classes that could be re-run for learning flexibility. Pointing out the subject matter in terms of content development, most of the students $(87 \%)$ stated that they preferred audio-video materials. In comparison, others preferred to have expository speech presentations by teachers (13\%) which is given in Table 3 below.

Table 3. Online learning class information

\begin{tabular}{|l|l|c|}
\hline \multicolumn{1}{|c|}{ Statements } & \multicolumn{1}{|c|}{ Responses } & Percentage \\
\hline Punctual class attendance & Yes & 95 \\
\hline & No & 5 \\
\hline $\begin{array}{l}\text { Conditions to meet ideal for } \\
\text { online learning material }\end{array}$ & Self-learning resources searching & \multicolumn{1}{|c|}{85} \\
\hline & $\begin{array}{l}\text { Provided by institutions in downloadable } \\
\text { soft file }\end{array}$ & 70 \\
\hline & $\begin{array}{l}\text { Content development by technological-based } \\
\text { platform }\end{array}$ & 88 \\
\hline
\end{tabular}

Students' perception of podcasts. To calculate the frequency and percentage for all the statements regarding students' perception in the podcast as the platform for course content development, a 5-point continuum scale was used, as shown in Table 4. The results showed many differences in students' perceptions of the materials/content development during the pandemic situation by applying distance online learning. $90 \%$ of the students who were research subjects gave their agreement statement that delivering or setting up learning materials by utilising a technological-based media in terms of podcast accelerated their learning skills, such as understanding and comprehension of subject matters or topics taught. It enabled them to relearn the materials in no time and space borders were to be downloaded for those who had a typical auditory learning style and needed remediation eases them to cope by looking out for their study needs. $70 \%$ stated that content development effectively transferred knowledge and built reciprocal communication among teachers and students. The results of students' preference for podcast content development by the subject course are described below.

Efficiency. It relates to the characteristics of minimising any occurred costs by utilising the objects successfully and adequately. The description of efficiency as one of the items included in the podcast content for the learning media is presented in Table 4. 
Table 4. Podcast efficiency items

\begin{tabular}{|l|c|c|c|c|c|}
\hline \multicolumn{1}{|c|}{ Items } & $\begin{array}{c}\text { 1 = Strongly } \\
\text { disagree (\%) }\end{array}$ & $\begin{array}{c}\mathbf{2}=\text { Disagree } \\
\text { (\%) }\end{array}$ & $\begin{array}{c}\mathbf{3}=\text { Neutral } \\
\mathbf{( \% )}\end{array}$ & $\begin{array}{c}\mathbf{4}=\text { Agree } \\
\mathbf{( \% )}\end{array}$ & $\begin{array}{c}\mathbf{5}=\text { Strongly } \\
\text { agree (\%) }\end{array}$ \\
\hline $\begin{array}{l}\text { The content in the } \\
\text { podcast is made along } \\
\text { with its goals and } \\
\text { functions. }\end{array}$ & 0.2 & 0.6 & 0.5 & 48.4 & 50.3 \\
\hline $\begin{array}{l}\text { It can be integrated or } \\
\text { synergized with other } \\
\text { learning methods. }\end{array}$ & 0.3 & 0.4 & 0.6 & 50.7 & 48 \\
\hline $\begin{array}{l}\text { The podcast learning } \\
\text { materials are accessible } \\
\text { on a low-cost budget. }\end{array}$ & 0.3 & 0.5 & 0.6 & 40.9 & 57.7 \\
\hline
\end{tabular}

Table 4 shows that most of the undergraduate students $(90 \%)$ had the same perspective on how to see the utilisation of podcasts as learning media and resources through agreeing with the statement (46.7\%) and strongly agreeing with the statement (52\%). In all items of efficiency including goals and functions, synergy and accessibility were found to be at the same perceptions for its positive contribution revealed from the average gained. Some of the respondents' comments also supported the questionnaire/ online survey results through interviews, which are as follows:

'The developed content for the learning materials is found to be simple. It can be seen how the learning objectives are in harmony with the functions of particular courses, for example, curriculum \& learning. It is very beneficial'. (Respondent 4)

'One of the major of most potential obstacles found in the instructional process is dealing with the external devices or any related media to be integrated with other theoretical models. For me, it is found so easy and supporting one another. It blends and completes the whole steps of learning experiences. So nice'. (Respondent 7)

'It is often discovered that learning materials are associated with something complicated and high costs. Through podcast content development for learning materials, it is not only economically proven as the primary material for production is your voice but also negotiable. It means that we do not have to rely on others for preparation for production. You can do it by your preference and style meeting to be suitable with the target market'. (Respondent 14).

There was improvement from the students' acceptance on dealing with efficiency in podcasting for learning media obtained from the interview session. It consisted of their poor understanding of its usage and how it works in assisting their study and feeling of doubt or being unsure whether using podcasts would help them reach their learning goals as they need to make notes and listen to it carefully. It exposed the shifting of their preference to the podcast. Some features available were found to be practical, automatic, effective, less time allotment and capable of being used anywhere and anytime. In addition, the content of the learning topics or information was adaptive. This meant that the content course was easy to integrate or assimilate to its objectives to give more value to a particular course. Consequently, it makes it possible for the bloated feeling of information to be decreased by applying the integrated learning within the course materials. 
Accessibility. The term accessibility leads to the model, work and product acquired in some ways. It improves the potential outcomes of any targeted goals from the students. It addresses various physical or perceptual impairments of students. The elaboration of accessibility items on podcast content development for smart online learning is given in Table 5 .

Table 5. Podcast accessibility items

\begin{tabular}{|l|c|c|c|c|c|}
\hline \multicolumn{1}{|c|}{ Items } & $\begin{array}{c}\mathbf{1}=\text { Strongly } \\
\text { disagree (\%) }\end{array}$ & $\begin{array}{c}\mathbf{2}=\text { Disagree } \\
\text { (\%) }\end{array}$ & $\begin{array}{c}\mathbf{3}=\text { Neutral } \\
\text { (\%) }\end{array}$ & $\begin{array}{c}\mathbf{4}=\text { Agree } \\
\text { (\%) }\end{array}$ & $\begin{array}{c}\mathbf{5}=\text { Strongly } \\
\text { agree (\%) }\end{array}$ \\
\hline $\begin{array}{l}\text { Easy to navigate. It } \\
\text { creates well-learning } \\
\text { experiences by more } \\
\text { engagement in specific } \\
\text { assistive technologies } \\
\text { users and low digital } \\
\text { literacy skills. }\end{array}$ & 0.9 & 0.8 & 0.9 & 31.7 & 65.8 \\
\hline $\begin{array}{l}\text { Proper listenability. It } \\
\text { enables students to learn } \\
\text { more in an auditory way } \\
\text { but assists them to work } \\
\text { through and understand } \\
\text { the context. }\end{array}$ & 0.3 & 1.0 & 1.2 & 56.5 & 41 \\
\hline $\begin{array}{l}\text { Convenient time } \\
\text { allotment. It enables } \\
\text { the learners to re-access } \\
\text { and revisit the content } \\
\text { for ones with learning } \\
\text { difficulties. }\end{array}$ & 0.4 & 0.7 & 1.0 & 60 & 37.9 \\
\hline
\end{tabular}

Referring to some items mentioned in Table 5, it can be noted that a major percentage of undergraduate students assumed its inclusion in the content of courses. It is shown in the results of the analyzed questionnaire or survey that an average of $49.4 \%$ agreed and $48.2 \%$ strongly agreed. It reflected how students found it to be successful technically within the content and media, all in one, in the form of a podcast. The results mentioned above were also convinced by the oral statement obtained from the interviews, which are as follows:

'The developed material for the learning through podcast provides an accessible website for any users. It has well color contrast on the background colors and text. All the features and icons can navigate and operate through a keyboard or any other device as in a smartphone'. (Respondent 10)

'To play the course content in the form of a podcast is super easy. It can be reached by control effortlessly by a clear label to enjoy. It also has a playback option, which is adjustable based on the needs of the user. It gives impacts how we feel about the material, lesson, media, and its understanding' (Respondent 26).

'It is just amazing to figure out that the content wrapped by podcast also providing its transcript of all the audio elements. It is beyond my imagination. What I have in mind for all this time is that podcast refers to audio production in the form of spoken or oral words. It is more than that as linked to the website where includes the sound effects, 
background component, and any other supporting parts to go along with the spoken words (Respondent 40).

It is essential to have accessibility in the podcast content production for users or audiences to play and enjoy with very few technical steps and additional complicated steps. The students stated that one of the points of interest from the podcast was that it could be played anywhere and at any time as convenient as possible from the users' point of view. It breaks the traditional concept of classical, traditional courses attended to in a classroom. It is very suitable for distance learning even in this pandemic era as an alternative learning media.

Interactivity. The items/aspects of interactivity in the podcast for learning refer to the interactions between users and computers in several mediums such as software, hardware and networks. The results of interactivity aspects are breakdown and presented in Table 6 .

Table 6. Podcast interactivity items

\begin{tabular}{|l|c|c|c|c|c|}
\hline \multicolumn{1}{|c|}{ Items } & $\begin{array}{c}\mathbf{1} \text { = Strongly } \\
\text { disagree (\%) }\end{array}$ & $\begin{array}{c}\mathbf{2}=\text { Disagree } \\
\text { (\%) }\end{array}$ & $\begin{array}{c}\mathbf{3}=\text { Neutral } \\
\text { (\%) }\end{array}$ & $\begin{array}{c}\text { 4= Agree } \\
\text { (\%) }\end{array}$ & $\begin{array}{c}\text { 5 = Strongly } \\
\text { agree (\%) }\end{array}$ \\
\hline $\begin{array}{l}\text { Focus on the target } \\
\text { audience. The } \\
\text { ideas and content } \\
\text { underline the users' } \\
\text { needs. }\end{array}$ & 0.3 & 0.4 & 0.7 & 45.2 & 53.4 \\
\hline $\begin{array}{l}\text { It is assisting the } \\
\text { audience in further } \\
\text { steps. It gains the } \\
\text { listeners to join, } \\
\text { follow, and do } \\
\text { something. }\end{array}$ & 0.5 & 0.6 & 0.9 & 20.8 & 77.2 \\
\hline $\begin{array}{l}\text { Asking for } \\
\text { participation. It } \\
\text { allows listeners, } \\
\text { questions, and } \\
\text { feedback as the } \\
\text { responses. }\end{array}$ & 0.6 & 1.3 & 2.0 & 70.2 & 25.9 \\
\hline
\end{tabular}

From Table 6, a summary of students' perceptions can be drawn with regard to their preferences on how they capture the podcast for learning; an average of $45.8 \%$ agreed and $52.2 \%$ strongly agreed with the items of interactivity. The interview results also showed similar outcomes, which are as follows:

'I feel like when I am listening to the materials delivered by podcast, and it gives me a relaxing atmosphere. It is more comfortable as we can place ourselves at best to receive the content taught. As a result, it is easy to understand. Thank you. It is inspiring and highly motivated'. (Respondent 39)

'The learning content in the podcast encourages us to get involved in the lesson by asking us for reasons and getting into the action by doing something. It is very inviting for practical applications to accomplish learning purposes. So exciting'. (Respondent 62) 
'I thought that it is a one-way communication learning model. It is different. There is an opportunity for the listeners or us to participate in the ongoing instructional process by podcast. The lecturers give us open-ended questions and collect them into the podcast's official website's comments box and social media channels. It is so much fun'. (Respondent 78).

The interactivity aspect in podcasts was found to be varied in the results by their preferences. Overall, based on the analysis from their comments and inputs got from the interviews, it was discovered that they were excited and highly motivated to take part and be involved in the lessons as they found it to be both attractive and interactive. It gained their positive feedback by asking for longer sessions of duration and separated them into continuous episodes. Besides, they also asked us for different topics for specific objectives with various courses, such as practical courses.

Quality. The term quality is closely related to the characteristics or features available on the products. The continuity of the long-term project of the podcast for learning also relies on the quality of its content to give value to the students. The items included in the quality of podcast for learning are explained in Table 7.

Table 7. Podcast quality items

\begin{tabular}{|l|c|c|c|c|c|}
\hline \multicolumn{1}{|c|}{ Items } & $\begin{array}{c}\text { 1= Strongly } \\
\text { disagree (\%) }\end{array}$ & $\begin{array}{c}\mathbf{2} \text { = Disagree } \\
\text { (\%) }\end{array}$ & $\begin{array}{c}\mathbf{3}=\text { Neutral } \\
\text { (\%) }\end{array}$ & $\begin{array}{c}\mathbf{4}=\text { Agree } \\
\text { (\%) }\end{array}$ & $\begin{array}{c}\mathbf{5}=\text { Strongly } \\
\text { agree (\%) }\end{array}$ \\
\hline $\begin{array}{l}\text { Understanding the topic. } \\
\text { The created subject } \\
\text { matter as of the topic } \\
\text { in the content valuable, } \\
\text { engaging, and unique } \\
\text { towards achieving } \\
\text { learning outcomes. }\end{array}$ & 0.1 & 0.7 & 2.5 & 60.5 & 36.2 \\
\hline $\begin{array}{l}\text { Knowing the audience. } \\
\text { It allows them to create } \\
\text { content meeting their } \\
\text { wants, preferences, and } \\
\text { needs. }\end{array}$ & 0.5 & 0.2 & 3.0 & 64.8 & 31.5 \\
\hline $\begin{array}{l}\text { It is providing } \\
\text { consistency. The learning } \\
\text { material is connected } \\
\text { and related from one to } \\
\text { another episode of the } \\
\text { specific course. }\end{array}$ & 0.3 & 1.0 & 3.5 & 15 & 80.2 \\
\hline
\end{tabular}

Table 7 provided the information about the items revealing the quality for the podcast as the content learning media. The average data gained from the questionnaires/ online survey presented that most of the students (46.8\%) stated that they agree and $48.9 \%$ strongly agree with their learning experiences in order to meet the quality of produced content by podcasts. The interview results also showed similar outcomes, which are as follows:

'The topic of materials delivered during the teaching-learning process is understandable. The teacher is well prepared in how to create the content to be exposed and well versed'. (Respondent 37) 
'In making the content for learning through podcasts, the teachers ensure that it will be vital for the learners during the transfer knowledge process. That is why I feel that the developed content seems to be meaningful and considering the target audience/ listeners/ learners demographic background such as; age groups, sex, and activities to tailor them with their needs'. (Respondent 52)

'In my opinion, learning a course or topic of a certain subject through podcast feels like having a series of films or something similar. The reason is that it has a continuation from one episode to another one. At the end of one session/episode, the teacher always gives us a teaser for the next meeting. I found it challenging and gaining our curiosity. It is fantastic'. (Respondent 80 ).

The quality of podcasts as a learning media has two aspects, namely information and goals. However, it was found that students misunderstood the concept by mixing information and goals in podcasts and courses. To overcome the appearing obstacles, we gave them deeper explanations by distinguishing both aspects in different questionnaires/online surveys to capture more valid and reliable data. The aspects for research data collections are presented on Table 8 below.

Table 8. Students' overall perception towards podcast learning

\begin{tabular}{|l|c|c|c|c|c|c|}
\hline \multicolumn{1}{|c|}{ Statements } & $\mathbf{1}(\mathbf{\%})$ & $\mathbf{2}(\mathbf{\%})$ & $\mathbf{3} \mathbf{( \% )}$ & $\mathbf{4}(\mathbf{\% )}$ & $\mathbf{5} \mathbf{( \% )}$ & Consensus \\
\hline $\begin{array}{l}\text { S1-I prefer my online podcast } \\
\text { class to be scheduled as in a } \\
\text { direct meeting classroom }\end{array}$ & 3.20 & 2.18 & 5.43 & 69.35 & 19.84 & 0.50 \\
\hline $\begin{array}{l}\text { S2-Podcast content } \\
\text { development for learning } \\
\text { activities assist me in } \\
\text { acquiring more the topic of } \\
\text { discussion well than in a } \\
\text { sitting classroom. }\end{array}$ & 3.40 & 3.11 & 6.35 & 57.40 & 29.74 & 0.51 \\
\hline $\begin{array}{l}\text { S3-The dynamic atmosphere } \\
\text { through a podcast for } \\
\text { learning enables me to } \\
\text { quickly establish two-way } \\
\text { communication among } \\
\text { teachers and peers. }\end{array}$ & 4.12 & 2.56 & 7.20 & 79.48 & 6.64 & 0.49 \\
\hline $\begin{array}{l}\text { S4-I feel more motivated } \\
\text { and relax, giving the } \\
\text { responses and feedback to the } \\
\text { meaningful learning process } \\
\text { through an online podcast for } \\
\text { learning. }\end{array}$ & 2.10 & 1.15 & 5.75 & 20.14 & 70.86 & 0.52 \\
\hline $\begin{array}{l}\text { S5-My listening skills have } \\
\text { increased since participating } \\
\text { in an online podcast for } \\
\text { learning }\end{array}$ & 2.55 & 3.14 & 6.35 & 10.60 & 77.36 & 0.45 \\
\hline $\begin{array}{l}\text { S6-I have more focus and a } \\
\text { better understanding of my } \\
\text { study when I could revisit and } \\
\text { replay the learning material } \\
\text { again. }\end{array}$ & 3.25 & 3.72 & 7.20 & 80.47 & 5.36 & 0.51 \\
\hline
\end{tabular}

(Continued) 
Table 8. Students' overall perception towards podcast learning (continued)

\begin{tabular}{|c|c|c|c|c|c|c|}
\hline \multicolumn{1}{|c|}{ Statements } & $\mathbf{1 ~ ( \% )}$ & $\mathbf{2 ( \% )}$ & $\mathbf{3}(\mathbf{\%})$ & $\mathbf{4}(\mathbf{\%})$ & $\mathbf{5}(\mathbf{\%})$ & Consensus \\
\hline $\begin{array}{l}\text { S7-Teachers has a proper } \\
\text { understanding of the learning } \\
\text { and supporting system of the } \\
\text { podcast for learning }\end{array}$ & 3.17 & 2.54 & 6.55 & 40.86 & 46.88 & 0.46 \\
\hline
\end{tabular}

Where,

1-the podcast for learning might be less effective;

2-the podcast for learning might be somewhat less effective;

3 -the podcast for learning might be equally effective;

4-the podcast for learning might be slightly more effective;

5 -the podcast for learning might be much more effective;

\section{Discussion}

This research aims to discover students' attitudes and perceptions towards using podcasts as a media development for the online learning environment and its characteristics for content development.

\subsection{Students' attitude and perception of using podcasts as online learning media}

Most of the students stated that podcasting was assumed to be significantly positive and contributed to their learning or material mastery. The gained percentage was $30 \%$ for very highly contributed, $40 \%$ for high contributed, $28 \%$ for fair contribution, $2 \%$ for less contributed and $0 \%$ for poor contributed by the supplemental type of podcast. Next, the repetitive podcast revealed $46 \%$ for very highly contributed, $32 \%$ for high contributed, $22 \%$ for fair contribution and $0 \%$ for less and inadequate contribution. This is in line with a previous research which stated that podcast acceptance could mediate and give effect to behavioural aspects such as social, cultural, expectancy, influences and conditions $[56,57,58,59]$. By accepting students, as can be seen from their attitude related to the usage of the podcast for content elaboration, in the higher education perspective. Bringing in podcasts for learning a medium to connect educators and students having meaningful, innovative online learning classes is more than an urgent need [69][70].

The analysis done connected to the students' preference on online learning content development by using podcast indicated that of the 84 students comprised that in all aspects of preference of courses content by podcasting in average by $50 \%$ stated on the third rate by definition well preferred. The developed content should cover features including efficiency, accessibility, interactivity and quality. It has been lauded for its flexibility in allowing students to be more productive by having listened while doing other duties/multi-tasking. Besides, it is very beneficial for note-taking practice for students [60], bringing in learning material as a podcasting tool. It has been very familiar for them to use it in iPods because listening to the music enables them to adopt 
a learning style for academic purposes [61]. From the technological device's point of view, the usage of podcasts could bring prospective progress practice in a higher level of education $[62,63]$.

\subsection{Podcast characteristics for material development}

As required, some methods applied to gathering data consist of spreading the questionnaire form of the online survey through Google Form and conducting interviews as the primary source to reach the stated objectives. The results of the research or the findings showed that they were in line with the four included aspects or characteristics of the podcast for learning including efficiency (consistent with learning goals and functions, integrated with other learning methods and accessible by low-cost budget), accessibility (easy to navigate, proper listenability and convenient time allotment); interactivity (focus on the target audience, further steps assistance and asking for participation) and quality (understanding the topic, knowing the audience and providing consistency). These followed the research findings carried out by Kalogiannakis and Papadakis [64], which revealed the four principles or aspects and included items for podcasting. It also stated how it makes it possible to utilise podcasting as the media for the student online and distance learning to improve their knowledge mastery and enhance students' personality [64]. Motivation and a two-way interaction between teacher and students leading to established listening and communication skills were the two most significant aspects offering different approaches within the content of courses to show their attitudes and perceptions towards the podcast for learning.

\section{Conclusion}

Motivation and a two-way interaction between teacher and students leading to established listening and communication skills were the two most significant aspects offering different approaches within the content of courses to show their attitudes and perceptions towards the podcast for learning [71]. In higher education, podcasting is relatively new to be maximised as the learning tool or platform to put and develop subject content delivered to the students in an online learning environment from smart learning. The survey shows that this technology mainly focuses on using audio to give the lecture to the students. This is in line with the findings from another relevant research stating that technology opens more opportunities in gaining optimum learning objectives [65]. A fundamental basis in the development of any aspects on educational transition should consider the users' attitudes and preferences to capture their responses dealing with online education, utilised tools, content development and other various attributes leading to a meaningful and effective instructional process. The results of this research can be used as a major baseline or fundamental basis for teachers, lecturers and educators on how to develop creative, effective and efficient learning media by considering their students' critical needs seen from the attitudes and perceptions for designing instructions through learning media. By being able to identify and develop proper media based on students' preferences, the more successful the learning goals' completion will be. 


\section{Acknowledgment}

The authors are grateful to Universitas Pendidikan Indonesia for the funding support through a research grant in 2020 .

\section{$7 \quad$ References}

[1] T. A. Angelo, “A teacher's dozen: Fourteen general, research-based principles for improving higher learning in our classrooms", AAHE Bulletin, vol. 45, no. 3-13, 1993. https://www. atu.edu/ir/docs/retentioninfo/retentionother/Thomas_Angelo s 14 Principles.pdf

[2] A. Bandura, "Self-efficacy: Toward a unifying theory of behavioral change", Psychological Review, 84, 191-215, 1977. https://doi.org/10.1037/0033-295X.84.2.191

[3] A. Bandura, Social foundations of thought and action: A social cognitive theory. Englewood Cliffs, NJ: Prentice-Hall, 1986.

[4] A. Bandura, Self-efficacy: The exercise of control. New York: W.H. Freeman, 1997.

[5] R. M. Bohlin, W. D. Milheim, \& K. J. Viechnicki, "A model for the motivational instruction of adults. Proceedings of selected paper presentations at the convention of the association for educational communications and technology". (ERIC Document Reproduction Service No. ED323918), 1990. https://files.eric.ed.gov/fulltext/ED362152.pdf

[6] S. Brittain, P. Glowacki, J. Van Ittersum, \& L. Johnson, "Podcasting lectures". Educause Quarterly, 29(3), 24-31, 2006. https://er.educause.edu/articles/2006/1/podcasting-lectures

[7] A. W. Chickering, \& Z. F. Gamson, Seven principles for good practice in undergraduate education. In A. W. Chickering \& Z. F. Gamson (Eds.), Applying the seven principles for good practice in undergraduate education (pp. 63-69). San Francisco: Iossey-Bass, 1991. https://doi.org/10.1002/t1.37219914708

[8] S. C. S. Cruz, \& A. A. A. Carvalho, "Podcast: a powerful web tool for learning history". In Proceedings of the IADIS International Conference e-Learning, 2007. Retrieved from http:// www.iadis.net/dl/final uploads/200711L040.pdf

[9] C. Dale, "Strategies for using podcasting to support student learning" [Electronic Version], Journal of Hospitality, Leisure, Sport \& Tourism Education, 6, 2007. https://doi.org/10.3794/ johlste.61.155

[10] K. M. Donnelly, \& Z. L. Berge, "Podcasting: Co-opting MP3 players for education and training purposes", Online Journal of Distance Learning Administration, 9(3), 2006. https:// www.westga.edu/ distance/ojdla/fall93/donnelly93.htm

[11] M. A. Eastin, \& R. LaRose, "Internet self-efficacy and the psychology of the digital divide", Journal of Computer-Mediated Communication, 6(1), 2000. https://doi.org/10.1111/ j.1083-6101.2000.tb00110.x

[12] C. Evans, "The effectiveness of m-learning in the form of podcast revision lectures in higher education", Computers and Education, 50(2), 491-498, 2008. https://doi.org/10.1016/j. compedu.2007.09.016

[13] R. Eynon, "Feminist perspectives on learning, media, and technology: recognition and future contributions", Learn. Media Technol, 43(1), 2018. https://doi.org/10.1080/17439884. 2018.1442848

[14] A. J. Fairchild, S. Jeanne Horst, S. J. Finney, \& K. E. Barron, "Evaluating existing and new validity evidence for the academic motivation scale", Contemporary Educational Psychology, 30(3), 331-358, 2005. https://doi.org/10.1016/j.cedpsych.2004.11.001

[15] V. Fernandez, P. Simo, \& J. M. Sallan, "Podcasting: A new technological tool to facilitate good practice in higher education", Computers \& Education, 53(2), 385-392, 2009. https:// doi.org/10.1016/j.compedu.2009.02.014 
[16] G. M. D. S. Ferreira, \& M. S. Lemgruber, "Great expectations: a critical perspective on open educational resources in Brazil”, Learn. Media Technol, 44(3), 315-326, 2019. https://doi. org/10.1080/17439884.2019.1639190

[17] M. Fisher, \& D. E. Baird, "Making learning work: Utilizing mobile technology for active exploration, collaboration, assessment, and reflection in higher education", Journal of Educational Technology Systems, 35(1), 3-30, 2006. Available: http://baywood.metapress. com/link.asp?id=4t10rx04113n8858. https://doi.org/10.2190/4T10-RX04-113N-8858

[18] D. R. Garrison, "Self-directed learning: Toward a comprehensive model", Adult Education Quarterly, 48(1), 18-33, 1997. https://doi.org/10.1177/074171369704800103

[19] P. L. Gay, A. Price, \& T. Searle, “Astronomy podcasting: A low-cost tool for affecting attitudes in diverse audiences" [Electronic Version], Astronomy Education Review, 5, 2006. https://doi.org/10.3847/AER2006003

[20] B. Gilbert, "Online learning revealing the benefits and challenges", Education Masters. Paper 303, 2015.

[21] M. Green, \& T. Sulbaran, "Motivation assessment instrument for virtual reality scheduling simulator", In T. Reeves, \& S. Yamashita (Eds.), Proceedings of world conference on e-learning in corporate, government, healthcare, and higher education 2006 (pp. 45e50). Chesapeake, VA: AACE，2006. http://www.anitacrawley.net/Resources/ Articles/Bollinger\%20Podcasting.pdf

[22] L. M. Guglielmino, "Development of the self-directed learning readiness scale", Athens, GA: The University of Georgia. Doctoral dissertation, 1977.

[23] M. J. Hannafin, "Guidelines for using locus of instructional control in the design of computer-assisted instruction", Journal of Instructional Development, 7(3), 6-10, 1984. https://doi. org/10.1007/BF02905753

[24] S. B. Heilesen, "What is the academic efficacy of podcasting?", Computers \& Education, 55(3), 1063-1068, 2010. https://doi.org/10.1016/j.compedu.2010.05.002

[25] M. L. Hung, C. Chou, C. H. Chen, \& Z. Y. Own, "Learner readiness for online learning: Scale development and student perceptions", Computers \& Education, 55(3), 1080-1090, 2010. https://doi.org/10.1016/j.compedu.2010.05.004

[26] W. Hürst, \& W. Waizenegger, "An overview of different approaches for lecture casting", In Paper presented at the proceedings of IADIS international conference mobile learning, Dublin, Ireland, 2006.

[27] A. E. Ifedayo, A.A. Ziden, \& A.B. Ismail, "Mediating effect of behavioral intention on podcast acceptance", Educ. Inf. Technol, 1-28, 2020. https://doi.org/10.1007/s10639-020-10385-Z

[28] H. Jackson, "Self [i.e.] reflective practice: revealing student engagement through the photographic performance of the self", Learn. Media Technol, 44(2), 144-161, 2019. https://doi. org $/ 10.1080 / 17439884.2018 .1563107$

[29] L. Jeamu, Y. Kim, \& Y. Lee, “A web-based program to motivate underachievers learning number sense", International Journal of Instructional Media, 35(2), 185-194, 2008.

[30] K. Jordan, "Imagined audiences, acceptable identity fragments, and merging the personal and professional: how academic online identity is expressed through different social media platforms", Learn. Media Technol, 1-14, 2019. https://doi.org/10.1080/17439884.20 20.1707222

[31] H. R. Kargozari, \& N. Zarinkamar, "Lexical development through podcasts", ProcediaSocial and Behavioral Sciences, 98(0), 839-843, 2014. http://doi.org/http://dx.doi. org/10.101 6/j.sbspro.2014.03.489

[32] K. J. Kim, S. Liu, \& C. J. Bonk, “Online MBA students' perceptions of online learning: Benefits, challenges, and suggestions", The Internet and Higher Education, 8(4), 335-344, 2005. https://doi.org/10.1016/j.iheduc.2005.09.005

[33] J. Koumi, Designing Video and Multimedia for Open and Flexible Learning. Routledge, London, 2006. https://doi.org/10.4324/9780203966280 
[34] R. Kozma, "Will media influence learning: Reframing the debate?" Educational Technology Research and Development, 42(2), 7-19, 1994. https://doi.org/10.1007/BF02299087

[35] M. Lazzari, "Creative use of podcasting in higher education and its competitive affection agency", Computers \& Education, 52(1), 27-34, 2009. https://doi.org/10.1016/j. compedu.2008.06.002

[36] M. J. W. Lee, \& A. Chan, "Reducing the effects of isolation and promoting inclusivity for distance learners through podcasting", Turkish Online Journal of Distance Education, 8(1), 85-104, 2007. http://tojde.anadolu.edu.tr/tojde25/pdf/article_7.pdf

[37] D. H. Lim, M. L. Morris, \& V. W. Kupritz, "Online vs. blended learning: Differences in instructional outcomes and learner satisfaction", Journal of Asynchronous Learning Networks, 11(2), 27-42, 2007. https://doi.org/10.24059/olj.v11i2.1725

[38] B. Lin, \& C. T. Hsieh, "Web-based teaching and learner control: A research review", Computers \& Education, 37(4), 377-386, 2001. https://doi.org/10.1016/S03601315(01)00060-4

[39] M. Maag, "Podcasting and MP3 players: Emerging education technologies", Computers Informatics Nursing,24(1),9-13,2006.https://doi.org/10.1097/00024665-200601000-00005

[40] M. McVay, "Developing a web-based distance student orientation to enhance student success in an online bachelor's degree completion program", In D. Program (Ed.), Practicum report presented to the. Florida: Nova South-eastern University, 2000.

[41] P. Mertala, "Paradoxes of Participation in the Digitalization of Education: a Narrative Account. Learning", Media and Technology, pp. 1-14, 2019. https://doi.org/10.31235/osf. $\underline{\text { io/8uh3v }}$

[42] L. Mitchell, "iPods cast a wide net for learning"-The age, 2006.

[43] D. A. Norman, "Podcasting for education", 2004. http://www.darcynorman.net/2004/10/30/ podcasting-for-education.

[44] B. Oliver, "Mobile blogging, 'Skyping' and podcasting: Targeting undergraduates' communication skills in transnational learning contexts" [Electronic Version], Microlearning, 107(4), 587-600, 2005.

[45] D. L. Rodgers, \& B. J. Withrow-Thorton, "The effect of instructional media on learner motivation", International Journal of Instructional Media, 32(4), 333-340, 2005.

[46] A. R. Roper, "How students develop online learning skills", Educause Quarterly, 30(1), 62-64, 2007.

[47] R. M. Ryan, \& E. L. Deci, "Intrinsic and extrinsic motivations: Classic definitions and new directions", Contemporary Educational Psychology, 25(1), 5, 2000. https://doi.org/10.1006/ ceps. 1999.1020

[48] S. Shaw, \& S. Polovina, "Practical experiences of and lessons learned from internet technologies in higher education”, Educational Technology \& Society, 2(3), 16-24, 1999. http:// www.ifets.info/journals/2_3/stephen_shaw.pdf

[49] H. Y. Shyu, \& S. W. Brown, "Learner control versus program control in interactive videodisc instruction: What are the effects of procedural learning?", International Journal of Instructional Media, 19(2), 85-95, 1992.

[50] A. Smith, "Government online, pew Internet and American life project", 2010. http://pewinternet.org/Reports/2010/Government-Online.aspx

[51] P. J. Smith, K. L. Murphy, \& S. E. Mahoney, "Towards identifying factors underlying readiness for online learning: An exploratory study", Distance Education, 24(1), 57-67, 2003. https://doi.org/10.1080/01587910303043

[52] A. Sun, \& X. Chen, "Online education and its effective practice: A research review”, Journal of Information Technology Education, 15, 2016. https://doi.org/10.28945/3502

[53] D. J. Swanson, "Tuning in and hanging out: a preliminary study of college students' use of podcast for information, entertainment, and socializing", Soc. Sci. J, 49(2), 183-190, 2012. https://doi.org/10.1016/j.soscij.2011.08.011 
[54] W. J. Tastle, \& M. J. Wierman, "Consensus and dissention: A measure of ordinal dispersion”, International Journal of Approximate Reasoning, 45(3), 531-545, 2007. https://doi. org/10.1016/j.ijar.2006.06.024

[55] S. Tavales, \& S. Skevoulis, "Podcasts: Changing the face of e-learning", 2006. ftp:// amd64gec.dyndns.org/WORLDCOMP06/SER4351.pdf

[56] T. L. Thompson, "Digital doings: curating work-learning practices and ecologies", Learn. Media Technol, 41(3), 480-500, 2016. https://doi.org/10.1080/17439884.2015.1064957

[57] U. Trautwein, O. Lüdtke, C. Kastens, \& O. K€oller, "Effort on homework in grades 5-9: Development, motivational antecedents, and the association with effort on classwork", Child Development, 77(4), 1094-1111, 2006. https://doi.org/10.1111/j.1467-8624.2006.00921.x

[58] R. J. Vallerand, L. G. Pelletier, M. R. Blais, N. M. Briere, C. Senecal, \& E. F. Vallieres, "The academic motivation scale: a measure of intrinsic, extrinsic, and motivation in education", Educational and Psychological Measurement, 52, 1003-1017, 1992. https://doi.org/10.1177/ 0013164492052004025

[59] D. L. Vess, "History to go: Why iTeach with iPods", The History Teacher, 39(4), 479-492, 2006. https://doi.org/10.2307/30037068

[60] R. Wagner, J. Werner, \& R. Schramm, "An evaluation of student satisfaction with distance learning courses", In Annual conference on distance learning. Whitewater, WI: University of Wisconsin, 2002.

[61] D. Warner, G. Christie, \& S. Choy, "Readiness of VET clients for flexible delivery, including online learning", Brisbane: Australian National Training Authority, 1998.

[62] A. Wise, J. Chang, T. Duffy, \& R. Del Valle, "The effects of teacher social presence on student satisfaction, engagement, and learning", Journal of Educational Computing Research, 31(3), 247-271, 2004. https://doi.org/10.2190/V0LB-1M37-RNR8-Y2U1

[63] C. Yeh, "An investigation of a podcast learning project for extensive listening", Language and Education in Asia, 4(2), 135-149, 2013. https://doi.org/10.5746/LEiA/13/V4/I2/A04/ $\underline{\text { Yeh }}$

[64] M. Kalogiannakis, \& S. Papadakis, "The dual form of further education of educators in ICT: technological and pedagogical training", In C. Constantinou, Z. Zacharias \& M. Papaevripidou (Eds.) Proceedings of the 8th International Conference on Computer Based Learning in Science, Heraklion, 30, 265-276, 2007.

[65] S. Papadakis, M. Kalogiannakis, E. Sifaki, \& N. Vidakis, "Evaluating Moodle use via Smart Mobile Phones. A case study in a Greek University", EAI Endorsed Transactions on Creative Technologies, 5, 16, 2018. https://doi.org/10.4108/eai.10-4-2018.154460

[66] S. Poultsakis, S. Papadakis, M. Kalogiannakis, \& S. Psycharis, "The management of Digital Learning Objects of Natural Sciences and Digital Experiment Simulation Tools by teachers", Advances in Mobile Learning Educational Research, 1(2), 58-71, 2021.

[67] S. Papadakis, M. Kalogiannakis, E. Sifaki, \& N. Vidakis, Access moodle using smart mobile phones. A case study in a Greek University. In Interactivity, Game Creation, Design, Learning, and Innovation, Springer, Cham, 2017.

[68] J. Chipps, J. Kerr, P. Brysiewicz, \& F. Walters, “A survey of University students' perceptions of learning management systems in a low-resource setting using a technology acceptance model", CIN Comput. Inform. Nurs, 33(2), 71-77, 2015. https://doi.org/10.1097/ CIN.0000000000000123

[69] E. Elstad, \& K. A. Christophersen, "Perceptions of digital competency among student teachers: contributing to the development of student teachers' instructional self-efficacy in technology-rich classrooms", Educ. Sci, 7(1), 27, 2017. https://doi.org/10.3390/educsci7010027

[70] T. Karakose, R. Yirci \& S. Papadakis, "Exploring the Interrelationship between COVID-19 Phobia, Work-Family Conflict, Family-Work Conflict, and Life Satisfaction among School Administrators for Advancing Sustainable Management", Sustainability, 13(15), 8654, 2021. https://doi.org/10.3390/su13158654 
[71] L. E. Dyson, “The Role of Podcasts in Studentsâ Learning?” International Journal of Interactive Mobile Technologies, 2(3), 17-21, 2008. http://dx.doi.org/10.3991/ijim.v2i3.526

[72] A. Bischoff, "M-Learning, Mobile Experimentation and Telepresence with Cell Phones and PDAs", International Journal of Interactive Mobile Technologies, 3(1), 49-52, 2008. http:// dx.doi.org/10.3991/ijim.v3i1.703

[73] F. Jamaldeen, P. Hewagamage, \& Y. Ekanayaka, "Design Guidelines for Creating Mobile Language Learning Applications", International Journal of Interactive Mobile Technologies, 12(3), 52-74, 2018. http://dx.doi.org/10.3991/ijim.v12i3.8153

\section{Authors}

Dr. Asep Herry Hernawan is an Associate Professor in Educational Technology, Universitas Pendidikan Indonesia. He has been the Head Director of Cibiru branch office campus from 2015 to present. He is also a lecturer and researcher in various scopes of studies covering curriculum development, educational human resources assessment, instructional design and model and elementary school education. His research interests include curriculum development, instructional design and learning media.

Dr. Laksmi Dewi is an Associate Professor in Educational Technology. She is the Head of the Postgraduate Curriculum Development Study Programme in the Educational Technology Department, Faculty of Education, Universitas Pendidikan Indonesia, Bandung, Indonesia. She is also a lecturer and researcher. Her research interest includes curriculum development.

Ahmad Fajar Fadlillah is a lecturer and researcher in the Educational Technology Department, Faculty of Education, Universitas Pendidikan Indonesia, Bandung, Indonesia. His research interest includes media audio development for online learning.

Budi Setiawan is a lecturer and researcher in the Educational Technology Department, Faculty of Education, Universitas Pendidikan Indonesia, Bandung, Indonesia. His research interests include mobile-assisted language learning and learning media development.

Article submitted 2021-06-18. Resubmitted 2021-08-12. Final acceptance 2021-08-12. Final version published as submitted by the authors. 